\title{
The Impact of Government Policies on Female Labor Force Participation Rates
}

\author{
Casey Abington \\ Northwest Missouri State University \\ 800 University Drive \\ Maryville, MO 64468, USA
}

\begin{abstract}
Labor force participation rates for men are higher than those for women in nearly every country in the world. This gap has significantly narrowed in the last century as more women have entered the labor force. However, more recently, the growth of participation by women has leveled off and even declined in some countries. This paper explores determinants of female labor force participation rates. The specific focus is on studying the effect of three relatively new and unique government policy variables - the existence of a law mandating paid or unpaid maternity leave, whether mothers are guaranteed an equivalent position following maternity leave, and the presence of a law mandating nondiscrimination based on gender in hiring. The study analyzes 177 countries from 2009 to 2017. The primary finding is that the existence of nondiscrimination laws based on gender in hiring is associated with higher female labor force participation rate.
\end{abstract}

Keywords: labor force participation rate, maternity leave, discrimination, gender

\section{Introduction}

Labor force participation rates for men are higher than those for women in nearly every country in the world. According to the World Policy Analysis Center (2017), globally, about three-fourths of working-age men participate in the labor force compared to only about half of working-age women. The gap between male and female participation rates has clearly narrowed in the last century as more women have entered the labor force. But, since 1990, the growth of participation by women has leveled off and even declined in some areas. In 2018, the worldwide male participation rate was about 75 percent, while the female participation rate was less than 50 percent (The World Bank, 2019).

The world average male and female labor force participation rates are shown below in Figure 1 for 1990 through 2018. Figure 2 shows these rates for only OECD countries. The graphs clearly show the substantial gap between male and female participation rates. Figure 1 shows that overall participation rates, both male and female, have been declining recently. Figure 2 shows that the gap has narrowed for the subset of OECD countries, with the female rate nearly 15 percent higher than the world average. Female labor force participation rates since 1990have remained mostly unchanged in low-income countries, gradually decreased in middle-income countries, and gradually increased in highincome countries.

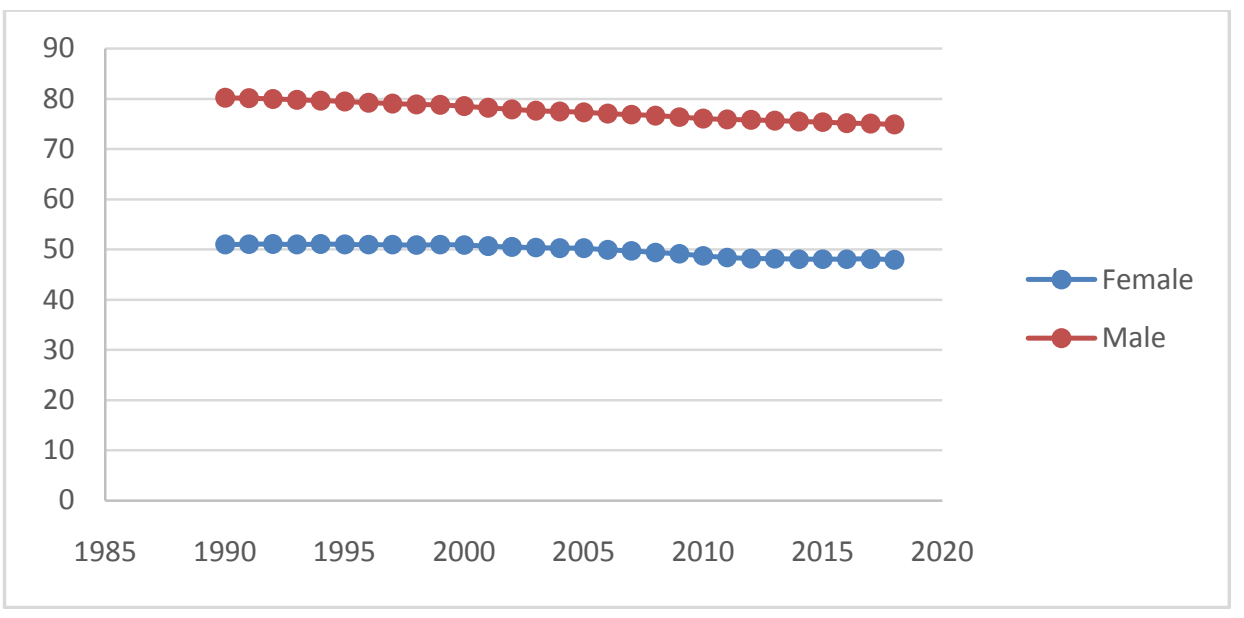

Figure 1: World average male and female labor force participation rates; percent of male and percent of female population ages 15 and older (modeled ILO estimate), respectively. Source: The World Bank. World Development Indicators. International Labor Organization, ILOSTAT database: https://databank.worldbank.org/data/source/worlddevelopment-indicators\# (October 18, 2019) 


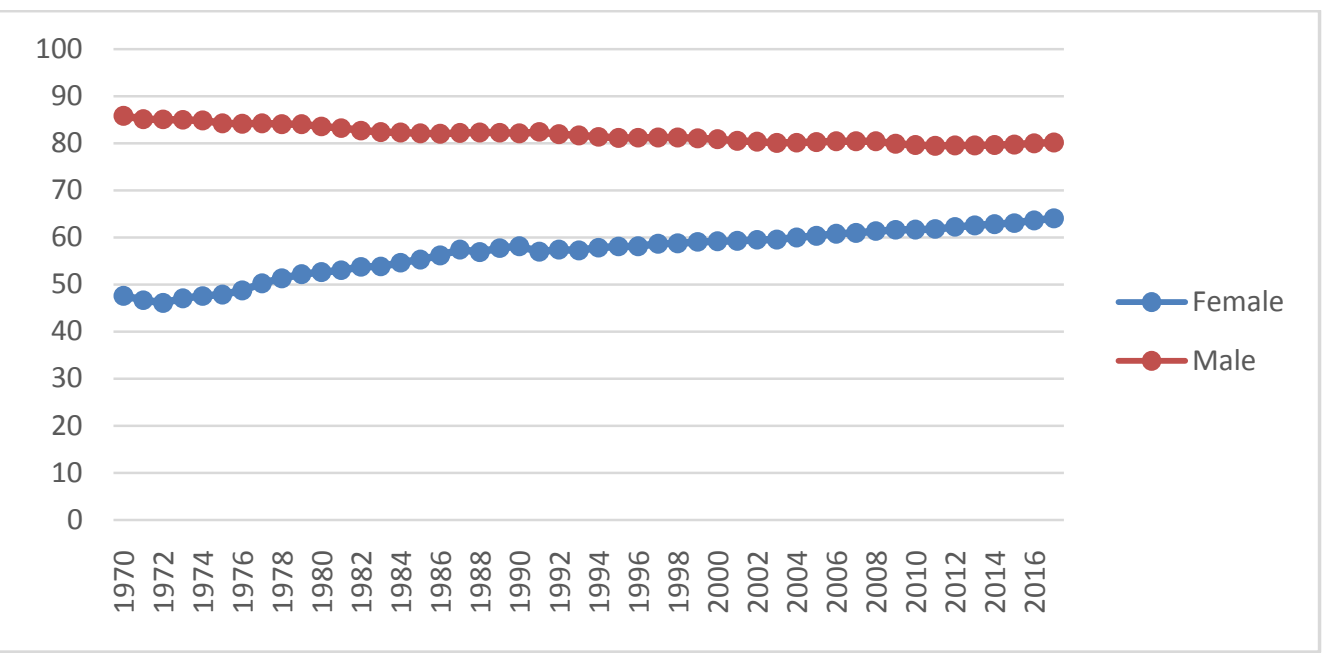

Figure 2: OECD average male and female labor force participation rates (percent of male and percent of female population ages 15-64, respectively). Source: Organization for Economic Co-Operation and Development (OECD). OECD.Stat:https://stats.oecd.org/ (January 24, 2019)

In addition to having lower labor force participation rates, women are also paid less than men. While the pay gap has decreased over the last two decades, women around the world still only earn about 77 percent of men's earnings (World Policy Analysis Center, 2017). There are several potential explanations for the gender pay gap. Olivetti and Petrongolo (2008) show that the gender pay gap tends to be smaller in countries where the female labor force participation rates are lower. They suggest that in some countries only women with certain characteristics, such as unmarried or no children, are entering the labor force. When women do enter the workforce, they are often underrepresented in higher-paying jobs and overrepresented in lower-paying jobs. Furthermore, Ortiz-Ospina Roser (2018) find that only about 19 percent of firms across the globe have a female manager. Even after controlling for differences in education, work experience, and sector, a significant gender pay gap exists (World Policy Analysis Center, 2017). This suggests that discrimination may be present. Therefore, discrimination is another issue that needs to be addressed when discussing women's labor market experiences.

How people spend their time is an important component of labor force participation. Looking at time use data reveals large and persistent differences between women and men. In general, and across countries, women spend significantly more time than men on unpaid work such as household chores and childcare. Furthermore, marriage and parenthood affect time use differently for men and women. Much of the difference is related to gender stereotypes and social norms. While progress has been made in recent decades and stereotypical gender roles are becoming less defined, there is still unequal distribution of unpaid work. Women tend to devote more time to household work and childcare than men.

Rubiano-Matulevich and Viollaz (2019) find that in 19 countries across income levels and from various regions, "women specialize in unpaid domestic and care work and men specialize in market work". In their study, they estimate a marriage and parenthood "penalty" on time use. They conclude that women of prime working age are the most penalized in terms of labor force participation, unpaid domestic work, and leisure time. Men, on the other hand, are not necessarily penalized and sometimes benefit in these same areas from parenthood and marriage. Based on this, it seems reasonable to assume that policies related to maternity and childcare will be important for women's labor market decisions.

According to Texas A\&M (2018), maternity leave in some form has been around since the 1800s. Currently, of the 193 countries in the United Nations, only 4 do not have a national paid parental leave law-New Guinea, Suriname, some South Pacific island nations, and the United States. The United States is the only high-income country that does not mandate paid maternity leave. The United States currently offers 12 weeks of unpaid leave. Over 50 other countries now offer six months or more of paid maternity leave. Overall, across income levels, 8 countries (including the United States) have no paid leave, 82 countries have paid leave of less than 14 weeks, 53 countries have paid leave between 14 to 25.9 weeks, 17 countries have paid leave between 26 to 51.9 weeks, and 33 countries have paid leave of 52 weeks or more (Deahl, 2016). Decades ago, United Nations representatives agreed on a goal of a minimum of 14 weeks of paid leave of two-thirds of a worker's salary up to a cap. This goal was set to help families who rely on income from mothers and to get and keep women in the labor force (Deahl, 2016). 
This paper explores the effect of policies related to maternity leave and discrimination on female labor force participation rates. While there are numerous studies that explore the determinants of female labor force participation, there are relatively few that analyze a large number of countries. There is also limited research focusing on the impact of government policies. This paper adds to the literature by focusing on the impact of government policies relating to maternity leave and discrimination for 177 countries. These policy variables are relatively new and unique to the literature. Finally, the most up-to-date World Development Indicator data is employed.

\section{Literature}

Claudia Goldin is a seminal source for research regarding the history of women's labor market experiences in the U.S.Much of her research focuses on factors that affect the female labor supply. Goldin (1990) finds that the narrowing gender earnings gap is one of the primary reasons behind the increasing married female labor supply. Goldin (1994) suggests that the female labor supply initially displayed a strong income effect and weak substitution effect as there was a shift from production at home to production in factories. Furthermore, she finds that the labor force participation rate of women increases with education, the ability to obtain white collar jobs after school completion, along with an increase in the substitution effect and a decrease in the income effect. Goldin (2006) shows the female labor force participation rate increased dramatically in the 1960s with the rise in aggregate demand and expansion of part-time jobs. During this time, feminism reemerged, birth control became available, divorce rates grew, and investment in education continued to increase.In the 1980s and 1990s, female labor supply was no longer highly elastic and was influenced less by husband's earnings. During this time, women's earnings rose relative to men's and women expanded into more jobs that were previously considered non-traditional.

Heckman and Killingsworth (1986) provide a detailed overview of the female labor supply in the U.S. and western economies. They find that hours of work per week, earnings, husband's earnings, and non-labor income are the most common variables examined in the literature. They also conclude that the literature indicates that the female labor supply is more elastic than the male labor supply. This suggests that women's decisions about work could be affected by policies more than those of men.

Many studies discuss the effect of social norms, culture, and stereotypical gender roles on women's labor supply. Greenwood, Seshadri, and Yorukoglu (2005) conclude that social norms regarding economic gender roles have been around for a long time and are very persistent. Alesina, Giuliano, and Nunn (2013) verify this finding and suggest that the impact of social barriers affecting female labor supply vary with income levels and other macroeconomic variables. Fernández(2013) finds that the cost of childbearing, cultural or social norms, and technological change in household production play an important role in explaining the large increases in the labor force participation rate of married women over the last century. The study focuses specifically on the revolution in social attitudes toward married women as illustrated by changes in laws affecting women and work and the depiction of married women in literature and press. One reflection of the change in social attitudes was the response to the following: "Do you approve of a married woman earning money in business or industry if she has a husband capable of supporting her?" In 1945, fewer than 20 percent agreed; in 1998, more than 80 percent agreed.

Much of the relevant literature suggests that education is a significant determinant of women's labor force participation. Eckstein and Lifshitz (2011) stressthe importance schooling on women's employment and labor force participation. They find that 33 percent of the increase in women's employment can be explained by rising education levels, and another 20 percent can be explained by higher wages and a narrowing gender wage gap. They find the remaining increase in women's employment to be unexplained by observable household characteristics such as changing preferences, cost of child rearing, and household maintenance.

Of the limited research exploring the effect of policies and benefits, most find a significant relationship with female labor force participation rates. Zveglich and Rodgers (2003) study the impact of maternity benefits on female workers in Taiwan. They find that the protective measures for female workers increase women's hours worked and employment. Blau and Kahn (2013) focus on the effect of "family friendly" policies on women's labor force participation rates in OECD countries. Their study suggests that availability of parental leave, paid parental leave, and laws giving workers the right to request a part-time work schedule are associated with higher female labor force participation and a smaller gender gap in participation rates. They also conclude that there is likely a tradeoff between these types of policies and women's career advancement. Ortiz-Ospina and Tzvetkova (2017) stress that women all over the world spend a substantial amount of their time on unpaid care work. Therefore, female labor force participation tends to increase when the time-cost of unpaid care work is reduced, shared equally with men, and/or made more compatible with market work. 
They discuss four primary drivers of female labor supply: maternal health, fertility, childcare and other family-oriented policies, and labor-saving consumer durables. They conclude that female employment tends to be higher in countries with higher levels of public spending on family benefits.

\section{Methodology and Data}

The methodology for this paper is a time-series analysis using fixed effects for both country and year. Employing a fixed effects model makes it possible to explore the effect of factors that vary over time and, therefore, to estimate variation within each country over time. Furthermore, the fixed effects method controls for omitted variables bias. The model is as follows

$y_{i t}=\beta x_{i t}+\alpha_{i}+u_{i t}$,

where:

$y_{i t}=$ dependent variable (female labor force participation rate) where $\mathrm{i}=$ country and $\mathrm{t}=$ time

$\alpha_{i}(\mathrm{i}=1 \ldots \mathrm{n})=$ unknown intercept for each entity (country) $-\mathrm{n}$ specific intercepts

$x_{i t}=$ one independent variable

$\beta$ is the coefficient on the independent variable

$u_{i t}=$ error term

This study employs World Development Indicator panel data for 177 countries from 2009 to 2017. The years and countries analyzed were determined by data availability, particularly the policy measures which were not available until 2009.

The dependent variable, female labor force participation rate, is measured as the percent of the female population aged 15 and older that is in the labor force.Three variables are included in the model to capture the effect of policies related to maternity leave and discrimination. The first policy variable reflects whether or not a country has a law that mandates paid or unpaid maternity leave for the mother. The second policy variable indicates whether mothers are guaranteed an equivalent position after maternity leave. This measure reflects whether employers are legally obligated to provide mothers with an equivalent or better position and salary than the employee had prior to maternity leave. The final policy variable captures whether there is a law mandating nondiscrimination based on gender in hiring. Specifically, this measure indicates whether there is a law that prevents or penalizes gender-based discrimination in the hiring process. It is hypothesized that each of these policies would have a positive effect on a country's female labor force participation.

In addition to thesepolicy variables, the control set includes other measures commonly found to be significant determinants of female labor force participation rates in previous studies ${ }^{1}$. Real gross domestic product (GDP) per capita is included to reflect a country's average income per person.

A positive correlation is predicted between real GDPper capita and female labor force participation. In the very poorest countries, women often work and produce at home for their own consumption and are therefore not part of the labor force. There are also likely to be more job opportunities in higher income countries.

The fertility rate is included in the model and represents the average number of children born per women in a country. Most studies show a negative relationship between fertility rates and female labor force participation ${ }^{2}$. As explained by Ortiz-Ospina and Tzvetkova (2017), lower fertility rates can free up time for women and therefore allow them to more easily enter the labor force.

As discussed earlier, the literature suggests that education is an important determinant of labor force participation rates. Specifically, almost all the literature shows that increases in education are associated with increases in female employment and labor force participation (Eckstein and Lifshitz, 2011). This study uses school enrollment ratios because the data was available for most countries. Educational attainment measures such as years of schooling were not available for enough countries and therefore could not be used in the model. Two enrollment ratios are included in the model. The primary school enrollment (percent gross) variable reflects the ratio of total female enrollment, regardless of age, to the female population of the age group that officially corresponds to the primary level of education. The secondary school enrollment (percent gross) ratio is analogous, but at the secondary level of education. See Table 1 below for summary statistics for all variables.

\footnotetext{
${ }^{1}$ See, for example, Heckman and Killingsworth (1986), Ortiz-Ospina and Tzvetkova (2017), Bloom et al. (2007), and Eckstein and Lifshitz (2011).

${ }^{2}$ See for example, Bloom et al. (2007) and Eckstein and Lifshitz (2011). 


\begin{tabular}{|l|l|l|l|l|}
\hline Variable & Mean & $\begin{array}{l}\text { Standard } \\
\text { Deviation }\end{array}$ & Minimum & Maximum \\
\hline $\begin{array}{l}\text { Female Labor Force } \\
\text { Participation Rate }\end{array}$ & 51.637 & 15.775 & 5.998 & 87.118 \\
\hline Maternity Leave Law & 0.968 & 0.176 & 0 & 1 \\
\hline $\begin{array}{l}\text { Nondiscrimination } \\
\text { Law }\end{array}$ & 0.481 & 0.500 & 0 & 1 \\
\hline $\begin{array}{l}\text { Equivalent Position } \\
\text { Law }\end{array}$ & 0.596 & 0.481 & 0 & 1 \\
\hline Fertility Rate & 2.877 & 1.438 & 1.055 & 7.515 \\
\hline $\begin{array}{l}\text { Primary School } \\
\text { Enrollment }\end{array}$ & 102.380 & 13.634 & 48.661 & 151.017 \\
\hline $\begin{array}{l}\text { Secondary School } \\
\text { Enrollment }\end{array}$ & 82.618 & 29.770 & 6.127 & 174.673 \\
\hline GDP per Capita & 13263.29 & 18515.28 & 212.547 & 108600.90 \\
\hline
\end{tabular}

Table 1: Summary Statistics

\section{Results and Conclusions}

The regression results for this study are shown below in Table 2. Of the non-policy related variables, the fertility rate, primary school enrollment, and GDP per capita are shown to be statistically significant. The fertility rate coefficient is negative, as hypothesized. This indicates that the higher a country's fertility rate (the more children born per woman), the lower the female labor force participation rate. The primary enrollment is shown to have a positive impact - higher primary school enrollment ratios are associated with higher female participation rates. Again, this is the expected relationship based on the literature. Finally, the model shows that female labor force participation rates increase with a country's GDP per capita. Countries with higher GDP per capita tend to have higher female participation rates.

\begin{tabular}{|l|l|l|l|}
\hline Dependent variable: Female Labor Force Participation Rate & \multicolumn{1}{l|}{} \\
\hline Variable & Coefficient & t-statistic & $\mathbf{P} \mid$ \\
\hline Maternity Leave Law & $\begin{array}{l}-1.224654 \\
(1.410239)\end{array}$ & -0.87 & 0.385 \\
\hline Nondiscrimination Law & $\begin{array}{l}0.4727069^{* *} \\
(0.3091163)\end{array}$ & 1.53 & 0.027 \\
\hline Equivalent Position Law & $\begin{array}{l}-0.0800708 \\
(0.6415242)\end{array}$ & -0.12 & 0.901 \\
\hline Fertility Rate & $\begin{array}{l}-1.285826 * * * \\
(0.3916593)\end{array}$ & -3.28 & 0.001 \\
\hline Primary School Enrollment & $\begin{array}{l}0.0050835 * * \\
(0.0116636)\end{array}$ & 0.44 & 0.663 \\
\hline Secondary School & -0.0116218 & -1.41 & 0.159 \\
Enrollment & $(0.008249)$ & 3.14 & 0.002 \\
\hline GDP per Capita & $0.0001118^{* * *}$ & & \\
\hline Constant & $\begin{array}{l}(0.0000356) \\
(2.42763\end{array}$ & 23.25 & 0.000 \\
\hline
\end{tabular}

Table 2: Regression Results

Robust standard errors are in parentheses. *,**, and *** indicate significance at the 10 percent, 5 percent, and 1 percent levels, respectively.

The focus of this analysis is to examine the impact of specific policy variables on female labor force participation rates. Of the policy variables, only the nondiscrimination law is shown to have a statistically significant effect. The other two policy variables included in the model-maternity leave laws and equivalent position laws - are found to be statistically insignificant. The coefficient on the nondiscrimination law variable exhibits the expected positive coefficient, indicating a direct association between the presence of nondiscrimination laws and female labor force participation rates. Countries with alaw mandating nondiscrimination based on gender in hiring have higher female labor force participation rates. 
This result suggests that women are more likely to work or to look for work when there is a law against gender discrimination in hiring. This could reflect that women are more likely to be hired in these countries or that women are more comfortable entering the labor force when they know they cannot be legally discriminated against based on gender. It could also be inferred from the results that discrimination based on gender in hiring could lead to lower female participation rates. Overall, the conclusion of this study suggests that countries may be able to increase the female labor force participation rate by enacting or strengthening laws that prevent and penalize discrimination based on gender in hiring.

\section{References}

Alesina, A., Giuliano, P., and Nunn, N. (2013). On the origins of gender roles: Women and the plough. The Quarterly Journal of Economics, 128(2), 469-530.

Blau, F.D. \& Kahn, L.M. (2013). Female labor supply: Why is the United States falling behind? American Economic Review:Papers \& Proceedings, 103(3): 251-256.

Bloom, D.E., Canning, D., Fink, G., \& Finlay, J. E. (2007). Fertility, female labor force participation, and the demographic dividend. Program on the Global Demography of Aging; Harvard School of Public Health Working Paper Series, September 2007.

Deahl, J. (2016). Countries Around the World Beat the U.S. on Paid Parental Leave. NPR All Things Considered. [Online] Available:https://www.npr.org/2016/10/06/495839588/countries-around-the-world-beat-the-u-s-onpaid-parental-leave

Eckstein, Z. and Lifshitz, O. (2011). Dynamic female labor supply. Econometrica, 79(6): 1675-1726.

Fernández, R. (2013). Cultural change as learning: The evolution of female labor force participation over a century. The American Economic Review, 103(1), 472-500.

Greenwood, J., Seshadri, A., and Yorukoglu, M. (2005). Engines of liberation. The Review of Economic Studies, 72(1), 109-133.

Goldin, C. (1990). Understanding the gender gap: An economic history of American Women. New York: Oxford University Press.

Goldin, C. (1994). The U-shaped female labor force function in economic development and economic history (No. w4707). National Bureau of Economic Research.

Goldin, C. (2006). The quiet revolution that transformed women's employment, education, and family.American Economic Review, 96(2):1-21.

Heckman J. and Killingsworth M. (1986) Female labor supply: A survey. In O. Ashenfelter\& R. Layard (Eds.), Handbook of labor economics, Volume I (pp. 103 - 204).New York: Elsevier.

Olivetti, C., \&Petrongolo, B. (2008). Unequal pay or unequal employment? A cross-country analysis of gender gaps. Journal of Labor Economics, 26(4), 621-654.

Ortiz-Ospina E. \&Tzvetkova S. Working women: Key facts and trends in female labor force participation [Online] Available:https://ourworldindata.org/female-labor-force-participation-key-facts (October 16, 2017)

Ortiz-Ospina E. and Roser, M. (2018). Economic inequality by gender. [Online] Available: https://ourworldindata.org/economic-inequality-by-gender

Rubiano-Matulevich, E. \&Viollaz, M.(2019). Gender differences in time use: allocating time between the market and the household. World Bank Group Policy Research Working Paper 8981, August 2019.

Texas A\&M Health. (2018). Fast facts: maternity leave policies across the globe. [Online] Available: https://vitalrecord.tamhsc.edu/fast-facts-maternity-leave-policies-across-globe/(January 23, 2018)

The World Bank. (2019). World development indicators: International Labor Organization, ILOSTAT database. [Online] Available:https://databank.worldbank.org/data/source/world-development-indicators\# (October 2018)

World Policy Analysis Center. (2017). Preventing gender-based workplace discrimination and sexual harassment: New data on 193 countries. [Online] Available: https://www.worldpolicycenter.org/sites/default/files/WORLDpercent20Discriminationpercent20atpercent20 Workpercent20Report.pdf

Zveglich, J. E. \& van der Meulen Rodgers, Y. (2003). The impact of protective measures for female workers. Journal of Labor Economics, 21(3): 533-555. 